\title{
The Export Potential of Innovative Bioresources of the Arctic in the Economic Zone of the Polar Silk Road
}

\author{
Elena Bogdanova \\ Department of Economics and Management, Institute of \\ Humanities \\ Northern Arctic Federal University \\ Severodvinsk, Russia \\ Sergey Andronov \\ National Medical Research Center for Rehabilitation and \\ Balneology \\ Ministry of Health of the RF \\ Moscow, Russia
}

\author{
Andrey Lobanov \\ National Medical Research Center for Rehabilitation and \\ Balneology \\ Ministry of Health of the RF \\ Moscow, Russia \\ Ruslan Kochkin \\ Medical sector \\ YNAO Arctic Research Scientific Center \\ Nadym, Russia
}

\author{
Ildikó Asztalos Morell \\ Department of Urban and Rural Development \\ Swedish University of Agricultural Sciences \\ Uppsala, Sweden
}

\begin{abstract}
Due to active exploration of the Arctic, employing shift workers from the southern regions, development of the Northern sea route and the Arctic shelf, there is a high need to increase resistance to cold, especially in extreme stress situations, maintain high efficiency and prevent diseases in the harsh conditions of the Arctic. The use of the Arctic plant and animal raw materials to produce innovative functional food products helps to improve human adaptation in cold environment with long polar days and nights, frequent geomagnetic changes affecting the psychological state of a person and his health to perform professional duties. China is interested in the cooperation in the field of biomedicine, because of the priorities mentioned in the Arctic strategy, aimed at its involving into the projects of the Arctic exploration. The paper highlights the perspectives of the export potential of innovative products, produced from the Arctic bioresources in the economic zone of the Polar silk road. Based on the data collected by the research team during scientific expeditions and laboratory biological and chemical studies of the Arctic plants (Shiksha black, brown Sphagnum, Cetraria, dwarf birch leaf, Siberian larch needles etc.) and local fish and meat in the Arctic zone of Western Siberia in 2014-19, minimum sufficient norms of consuming Arctic traditional food products and the samples of innovative functional products were developed: "Heart of the North", sets of fast cooking hot food "Teplorod" and "Operator", Bread "Port Sabetta", drink "Yamal IRI", chocolate "Yamal lichen" and
\end{abstract}

chewing marmalade "Yamal herbarium". The reported study was funded by RFBR, project number 18-010-00875.

Keywords: innovative bioresources, Arctic, Western Siberia, economic zone of the Polar silk road

\section{INTRODUCTION}

Due to active exploration of the Arctic, employing shift workers from the southern regions, development of the Northern sea route, there is a high need to increase resistance to cold, especially in extreme stress situations, maintain high efficiency at work and prevent diseases in the harsh climatic conditions. Improvement of human adaptation models is especially important for the polar regions, because of extreme cold stress, long polar days and nights, frequent geomagnetic activity affecting the psychological state of people and their health to perform professional duties. So, improving resistance to cold stress is an important task to ensure the safety of people living and working in the Arctic region (military, sailors, fishermen, drivers, builders, shift workers, workers), etc.

This line of research is especially relevant for partners from China, since, in accordance with the Arctic strategy and positioning of the country in this region [1-3], the investment contribution to projects related to oil and gas and energy complexes, international scientific strategic planning, as well as transit commercial shipping is increasing. As a result, the share of highly qualified personnel attracted to perform work in the economic zone of the Polar Silk Road, is growing. 
Besides that, "climate change impacts lead to alterations in migration patterns and the displacement of exposed native communities and peoples in the Arctic region, forcing them to leave their homes and traditional ways of life" [4]. It makes developing adaptation models necessary for indigenous communities. It was noticed that changing the approach towards a knowledge-systems-based framework would also contribute to the "development of more concrete policies and strategies for adaptation of Arctic native communities" [4].

Adaptation to extreme Arctic climatic conditions can be increased by changing a diet and implementing functional food products based on the Arctic bioresources (plant and animal raw materials). They have a huge value in pharmaceuticals industry as "molecules or templates for discovery or further development of new drugs" [5]. Recent genetic based studies showed that "the diversity of the polar region is much more than previously predicted. In order to survive in the cold, extreme and inhospitable environment conditions, polar organisms produce an array of unique metabolites which confer an advantage and offers protection from predation. Out of all the natural products reported from polar organisms, $38 \%$ of them showed bioactivity of pharmaceutical relevance" [5]. This illustrates the tremendous potential of the polar organisms as a source of new therapeutic agents for infectious and lifestyle associated diseases.

Using unique properties of the Arctic bioresources to develop functional food products correlates the current trend of bioeconomic "Green Food Processing" approach which is "the result of a whole chain of values in both senses of the term: economic and responsible, starting from the production and harvesting of food raw materials, processes of preservation, transformation, and extraction together with formulation and marketing" [6].

Bioeconomy linked to technology and innovation management research [7] is also prospective for European studies since in an economy and a society in recession within a globalized environment "raw materials and food products have multiple entries into the EU" [8]. It's a new field for multidisciplinary research aimed at exploration of the unique properties of the Arctic bio materials for developing new functional food products to increase efficiency and resilience to extreme stress factors, both implementing Arctic indigenous peoples' experience and innovative technologies. The importance of such "knowledge co-production" is highlighted by M.D. Robards et al.: "Global changes in climate, connectivity, and commerce are having profound impacts on the Arctic environment and inhabitants. There is widespread recognition of the value of incorporating different worldviews and perspectives when seeking to understand the consequences of these impacts" [9]. This will allow science, representatives of the "indigenous" traditional economy and the pharmaceutical industry to move from supplying the world market with bioresources of the Russian Arctic to exporting biomedical and biopharmaceutical innovative products meeting international quality standards.

Implementation of Arctic indigenous people's experience is especially valuable because of their identity and long-term isolation which guarantee the preservation of the traditions, "the intergenerational transmission of knowledge about the use of natural resources, and the preservation of a sustainable eco world for its people" [10].

The aim of this study was to prove that innovative functional food products made of the Arctic bioresources have high export potential in the economic zone of the Polar Silk Road.

The objectives of this paper were to: 1) study the impact of the bioresources collected in the Arctic zone of Western Siberia (Shiksha black, brown Sphagnum, reindeer blood, fat of local YNAO fish, venison etc.), on human health and longterm adaptation to the harsh climatic conditions of the Arctic; 2) present examples of the innovative functional food products produced from the Arctic bioresources; 3) highlight the prospects and the barriers of their export to China and other countries interested in exploration of the Arctic.

\section{METHODS}

The article describes current trends related to the study of the developing innovative functional food products based on bioresources in the Arctic zone of Western Siberia (YamalNenets Autonomous Okrug - YNAO). This region is a part of the High North, and more than half of its territory is located above the Arctic Circle.

This research takes a multidisciplinary approach that draws on methods used in the fields of economics, medicine, and sociology. It was conducted using the methods of a systematic approach to the study of socio-economic problems of regions to assess the main trends in the development of the socioeconomic situation in the region. The conceptual issues related to developing the export potential of innovative functional food products based on Arctic bioresources were analysed using the theory of economic globalization, regional and industry integration in the field of social problems of human health and human ecology. The study also applied economic and mathematical modelling to build risk models based on non-linear logit regression with step-by-step inclusion of variables by the maximum likelihood method, cluster analysis, k-means method. The Varda method was chosen as a method for determining the distance between clusters. The results were analysed using STATISTICA 8.0 (StatSoft Inc., USA).

The primary sources were the data collected from interviews, surveys and medical examinations of 1326 residents of YNAO, including 590 Indigenous Peoples during expeditions to the Nyda settlement, the Nydinskaya tundra, the Tazovsky settlement, the Tazovskaya tundra, the Nakhodka tundra, the Gyda and Gydansky settlements, the Yavai-Salinskaya tundra, the Seyakha settlement, the Seyakhinskaya and Tambeyskaya tundras (located along the southern coast of the $\mathrm{Ob}$ Bay), the northeast coast of the Yamal Peninsula, and the Tazovsky and Gydansky Peninsulas. The data were collected in summer (August) and winter (March and November) in 2014-19.

Two hundred and fifty-two semi-structured interviews were conducted based on the interview guide developed and approved by the YNAO Arctic Scientific Research Centre. Two hundred and thirty-eight surveys with fixed questions 
were received. All participants over 18 years of age provided written informed consent. Participants' personal data were anonymised, numbered, and added to the databases of the Northern Arctic Federal University project team.

Secondary sources used in the study consisted of official information requested from local authorities, public statistical data, and official government reports.

The study was approved by the Ethics committee of YNAO Arctic Scientific Research Centre on January 18, 2013 (approval protocol № 01/1-13).

\section{RESULTS}

The results of the conducted medical examinations and interviews provided the data for working out the minimum sufficient norms of consumption of traditional food products (local meat and fish) to decrease the risk of the most frequent diseases among the Arctic population: hypertension, chronic bronchitis and overweight. Implementing non-linear logit regression models proved that for reducing the risk of hypertension it's necessary to take $470 \mathrm{~g} /$ day of venison twice a week, $50 \mathrm{~g} /$ day - reindeer liver, $810 \mathrm{~g} /$ day - Schekur fish 4 times a week, $325 \mathrm{~g} /$ day - Smelt fish, $230 \mathrm{~g} /$ day - Ryapushka fish, $50 \mathrm{~g} /$ day - Pike fish 0.4 times a week, $22 \mathrm{~g} /$ day - Burbot fish; for reducing the risk of chronic bronchitis it's enough to take $190 \mathrm{~g} /$ day of venison, $158 \mathrm{~g} /$ day - Schekur fish, $40 \mathrm{~g} /$ day - Pike fish 0.2 times a week; for reducing the risk of overweight it's necessary to take $160 \mathrm{~g}$ /day of venison, 440 g/day - Whitefish, $96 \mathrm{~g} /$ day - Siberian whitefish. It was revealed that the control group consuming venison 3 times a week or more often differed from the group which didn't take venison: it had lower body mass index (-20.0\%; U-2577.0; $\mathrm{p}=0.04)$, significantly higher fat-free body weight $(+20.0 \%$; U2279.0; $\mathrm{p}<0.01)$, significantly lower total fluid $(-10.0 \%$; U2352.0; $\mathrm{p}<0.01)$ and intracellular fluid $(-15.0 \%$; U-2252.0; $\mathrm{p}=0.03$ ). A positive correlation between the daily consumption of venison and the concentration of high-density lipoproteins in the blood was proved ( $\mathrm{rs}=0.5 ; \mathrm{p}=0.003$ ), as well as positive correlation between the consumption of Pike fish and the index of functional oxygen consumption in the tissue ( $r s=0.6$; $\mathrm{p}<0.001)$.

Based on these minimum sufficient norms of consumption of the Arctic traditional food products and the results of laboratory biological and chemical research of the Arctic plants (Shiksha black, brown Sphagnum, Cetraria, dwarf birch leaf, Siberian larch needles) and local fish and meat, the project team of the YNAO Arctic Scientific Research Centre developed the innovative functional food products: "Heart of the North" (made of reindeer blood), sets of fast cooking hot food "Teplorod" and "Operator", Bread "Port Sabetta", drink "Yamal IRI", chocolate "Yamal lichen" and chewing marmalade "Yamal herbarium".

\section{DISCUSSION}

When analyzing the unique properties of plant and animal raw materials, it is necessary to study the experience of the Arctic indigenous peoples, since traditional food is not only a set of food products but also an integral element of the culture of nomadic peoples, means of prevention and treatment, a major factor in increasing the level of adaptation to the conditions of the Arctic. Consumption of traditional foods is an integral component to good health among Indigenous Peoples influencing both physical health and social wellbeing.

It is important not to delay studying the indigenous experience since Arctic species and ecosystems are experiencing pressure from rapid biophysical changes, including ocean warming and acidification, diminishing sea ice, and environmental contamination. These biophysical changes are paralleled by rapid socioeconomic changes in indigenous communities, which have resulted in the decreased harvest and consumption of traditional food, and the increased representation of market food, often nutrient-poor and energydense, in the diet. Analysing nutritious trends in Inuits, TiffAnnie Kenny mentioned that these dietary changes may be further exacerbated by climate-related declines in food availability and access, or food safety concerns from environmental contaminants, and may have significant repercussions for public health in Arctic communities that are already burdened by significant disparities in food security and health [11-12]. It absolutely correlates cultural and nutritious trends among Nordic communities [13] and indigenous peoples in the Russian Arctic.

The unique diet of the Arctic indigenous inhabitants using raw local fish, meat, reindeer blood and liver always attracted the attention of researchers. The first scientific descriptions of the Arctic inhabitants' nutrition belong to Pierre Martin de La Martinière in "Voyage des pays septentrionaux: dans lequel se void les mœurs, maniere de vivre, \& superstitions des Norweguiens, Lappons, Kiloppes, Borandiens, Syberiens, Samojedes, Zembliens, Islandois" (1671), who described the lifestyle of the Norwegians, Laplanders, Kilops, Borandais, Siberians, Samoyeds, New Zealanders and Icelanders. In the 19th century, the Samoyeds' nutritious traditions were presented by F.I. Belyavsky in "Trip to the Arctic Sea" (1859) and by P.I. Tretyakov in "Turukhansk Territory, its Nature and Inhabitants" (1869), as well as the Nenets' food was described by Yu.I. Kushelevsky (1858). In recent decades, the contribution to the study of YNAO residents' nutrition was made by A. Buganov et al. (1994, 2000), S.I. Mataev et al. (1998, 2011), L.S. Polikarpov et al. (1996), L.P. Lobanova et al. (2006) who proved the impact of traditional nutrition on the risk of circulatory diseases in the High North. In early XXI century the nutrition of the Indigenous population of YNAO was studied by B.M. Raengulov et al. (2001); by L.A. Beresneva (2005) showed the effect of traditional nutrition on immunity; by L.P. Lobanova et al. (2013) studied the influence of traditional nutrition on body composition, metabolism and autonomic regulation [14]; by A.I. Popov and Lobanov A.A. (2013) analised food sovereignty in national villages of YNAO, and by I.E. Ionova (2004) studied Indigenous Peoples' diet and calculated the consumption of macro- and micronutrients. However, there was a significant "gap" in the last research: local fish and meat were not analysed, and their chemical composition was extrapolated that significantly reduced the accuracy of the calculations. This distortion was especially critical for the inhabitants of the 
tundra since local fish and venison prevail in their diet. A. Martinchik and Baturin E.V. (2010) studied the nutrition of the Indigenous and migrated population of the $\mathrm{Ob}$ river. However, the obtained results cannot be extrapolated to other areas of YNAO since the diet of the population in Priobie enriched with fish differs significantly from the nutrition of nomadic reindeer herders.

In 2014-19, the projects team of the YNAO Arctic Scientific Research Centre conducted laboratory analysis which proved high efficiency of such YNAO local bioresorces as venison, Pike fish and Schekur fish for adaptation to cold stress and geomagnetic activity in the Arctic. These products provide a human organism with recommended daily norm of protein, micro and macro elements. Whitefish and Schekur fish are enriched with fats and have sufficient energy value. Venison is also characterized by a high amount of phosphorus (P) and magnesium (Mg). Schekur fish contains a lot of potassium $(\mathrm{K}), \mathrm{P}$, manganese $(\mathrm{Mn}), \mathrm{Mg}$ and chromium $(\mathrm{Cr})$. Pike fish is rich in $\mathrm{K}, \mathrm{P}, \mathrm{Mn}, \mathrm{Mg}$, iron $(\mathrm{Fe})$ and $\mathrm{Cr}$. It was proved that the diet enriched with venison statistically significantly increases the anti-atherogenic fractions of blood lipids, prevents overweight, and improves microcirculation, tissue fluid metabolism and antioxidant protection of the body from free radicals. It explains high efficiency in adaptation to cold stress, as well as increased preventive activity from frostbite and survival under hypothermia. Consumption of local fish increases the elasticity of the vascular wall and reduces the risk of heart attacks and strokes. The diet enriched with Pike fish contributes to the absorption of oxygen in tissues and strengthening of peripheral blood circulation. That is also effective for increasing resistance to cold.

Arctic plants can be used for producing functional food products since they have a positive impact on improving adaptation mechanisms to the harsh climatic conditions of the Arctic. For example, Shiksha black (Empetrum nigrum) increases resistance to cold stress. It was used by Nenets, Khanty, Zyryans, Yakuts to reduce fatigue during high physical exertion and to treat neurological diseases. Our laboratory experiments proved that those who took its extract 30 minutes before cooling the face and hands showed almost two times better results in accuracy and speed of performing their work than in the control group. This plant is also effective for providing cerebroprotective, anticonvulsant and angioprotective effects (the vascular age index decreased by $60 \%$ compared with the control group $(\mathrm{p}<0.001))$, sustainable work of nervous system and control of blood pressure (decreased by almost $30 \%$ compared to the control group $(p=0.03))$ in the days of geomagnetic activity. Brown Sphagnum has positive impact on removing toxic products from a human organism resulting in high hypoallergenic and detoxification effect, as well as prevention of bronchitis and bronchial asthma. Statistically significant decreasing the number of attacks and need for bronchodilators, increasing discharge of sputum was proved. This makes both plants (Shiksha black and brown Sphagnum) promising for producing functional food products food for employees of oil and gas, chemical and radiological industries.

Based on the Arctic bioresources the project team of the YNAO Arctic Scientific Research Centre developed innovative functional food products aimed at increasing adaptation to the harsh climatic conditions of the Arctic. A biologically active product "Heart of the North", produced from reindeer blood, statistically significantly increases the physical strength, resistance to cold stress, prevents overweight. A set of fast cooking hot food "Teplorod", based on Pike fish, Burbot fish, Shiksha black extract, lipid and mineral additives, improves resistance to cold. A set of fast cooking hot food "Operator", including Sphagnum biscuits, an extract of Shiksha black and Schekur's fat, reduces the risk of magnetotropic reactions, increases concentration, efficiency, and stable operation of nervous system during geomagnetic activity. Therefore, this set is effective for employees operating mechanisms in the Arctic. Bread "Port Sabetta" removes toxic and allergenic products from an intestine, normalizes digestion, suppresses putrefactive and fermentation processes, causes a feeling of prolonged saturation, reduces excess fluid buildup in tissues, has an adaptogenic effect during magnetic storms while experiencing mental and physical stress. This product is especially convenient for shift workers at remote areas because it can be stored for a long time without packaging, does not require preservatives, does not dry or grow mouldy for a long time. Drink "Yamal IRI" made of Shiksha black and Siberian larch, increases resistance to cold, efficiency of performing precise operations during magnetic storms, normalizes vegetative balance in sympathotonics. Chocolate "Yamal lichen" has antidepressant and antioxidant effects, increases adaptive capacity of employees experiencing significant mental and physical stress, normalizes digestion. Chewing marmalade "Yamal herbarium" also increases resistance to stress, has an antioxidant effect, as well as reduces glucose absorption that prevents overweight and diabetes [15].

These innovative functional food products can be examples which prove the export potential of the Arctic bioresources (Shiksha black, brown Sphagnum, reindeer blood, fat of local YNAO fish, venison etc.) as well as other products, i.e. reindeer pants which are a unique Arctic bioresource enriched with omega 3 fatty acids and usnic acid resulting in antiseptic, anti-tuberculosis, antitumor activity. A Siberian reindeer lives in more severe climatic conditions than a red deer and a sika deer that provides the extremely high adaptogenic activity of its pants. Export potential of this bioresource is especially high in the economic zone of Polar silk road, caused by the aging of the population in China [16], combined with an increase in the welfare, expansion of middle class, and development of pharmaceutical industry. During last five years (2015-19) pants production became a leading source of income for reindeer herders in Yamal and Gydan Peninsulas of YNAO (the overall official income per season is about $1-2.5$ billion rubles). The exact amount of pants sales is unknown since mostly this trade is carried out illegally. Selling pants as a raw material but not a produced pharmaceutical product is one more issue to be addressed. Siberian reindeer herders are usually not so careful with choosing correct time for cutting pants. However, it's critical for the quality of pants and has high impact on their pricing policy and profitability of this business. Researchers of some Russian institutions (i.e., Research Institute of Farms of the High North of the Russian Agricultural Academy, Northwest 
Regional Scientific Center of the Russian Agricultural Academy, Yakutsk Agricultural Institute, All-Russian Scientific Research Institute of Pants Reindeer Husbandry of the Siberian Branch of the Russian Academy of Agricultural Sciences, Siberian Research, Design and Engineering Livestock Research Institute of the Siberian Branch of the Russian Academy of Agriculture, Altai State Medical University, Far Eastern State Agrarian University) are looking for the solutions to increase quality of reindeer pants.

At the same time, reindeer herders do not have appropriate facilities to process (at least, primarily) and preserve pants. Each "link" of this "food chain" increases the cost of pants production by 2-4 times. Therefore, reindeer herders prefer to avoid these complicated procedures and sell pants as raw materials in bulk. That's why it's almost impossible to provide export attractiveness of the pants until the quality of this bioresource is increased and meets quality control requirements adopted in China, with quality and veterinary certificates recognized in both countries. Otherwise, national pharmaceutical industry should offer appropriate facilities for pants processing to reindeer herders and initiate developing innovative functional food products and medications based on pants which can be later exported to China and other countries.

The development of innovative approaches to the use of natural plant and animal raw materials in the Arctic should be based on using both the Arctic indigenous peoples' experience and innovative technologies.

It is necessary to solve a number of conceptual issues related to making an economic model for the development export potential of these innovative products based on the theory of economic globalization, regional and industry integration in the field of social problems of human health and human ecology; to solve the problems of infrastructural development of the Russian Arctic regions (primarily the Nenets and Yamal-Nenets Autonomous Okrugs) in the field of procurement, processing, storage of bio-raw materials, and producing biomedical and biopharmaceutical innovative products, as well as development of an integrated economic model, including supply of bio-raw materials for producers, passing stage-by-stage quality control with product certification, logistics through exporting companies to the consumers.

One more prospective field of studies is developing medicinal plant and animal databases for sharing "ethnopharmacological knowledge" [17] collected during fieldwork and obtained from Indigenous communities.

Following international quality standards will ensure the growth of the export potential of the Russian Federation in this field. It is urgent to revise current economic paradigm and move from supply of biological resources (as a raw material) of the Russian Arctic to the world market, to the export of biomedical and biopharmaceutical innovative products that meet international quality standards, have high level of profitability and increase Russia's competitiveness at the international food market. Moreover, the development of international cooperation with BRICS countries (primarily China) in the Arctic will develop a new economic model for improving well-being of Indigenous population due to the prospects of growth of innovative production, positive impact on labour market, while preserving traditional lifestyle.

Thus, developing innovative functional food products, based on the Arctic bioresources, is not only contribution to maintaining health of the Arctic residents and increasing adaptive capabilities of people working in extreme conditions, but also an important socio-economic project that provides Indigenous population with work and preserves their traditional lifestyle, brings previously unused biological resources of the Arctic into the world market and develops a high-tech cluster of bio-production in the High North.

\section{ACKNOWLEDGMENTS}

The reported study was funded by RFBR, project number 18-010-00875.

\section{REFERENCES}

[1] S. Yilmaz, "Exploring China's Arctic Strategy: Opportunities and Challenges", China quarterly of international strategic studies, 2017, vol. 3 , issue 1, pp. 87-78.

[2] G. Xu, "China's Arctic interests and policy: history, legal ground and implementation", Mirovaya ekonomika i mezhdunarodnye otnosheniya, 2016, vol. 60, issue 2, pp. 52-62.

[3] J. Peng, N. Wegge, "China's bilateral diplomacy in the Arctic", Polar Geography, 2015, vol. 38, issue 3, pp. 233-249.

[4] D.R. Manrique, S.Corral, and Â.G. Pereira, "Climate-related displacements of coastal communities in the Arctic: Engaging traditional knowledge in adaptation strategies and policies", Environmental Science and Policy, July, 2018, vol. 85, pp. 90-100.

[5] V.C. Tripathi, S. Satish, S, Horam, and S. Raj et al., "Natural products from polar organisms: Structural diversity, bioactivities and potential pharmaceutical applications", Polar Science, December, 2018, vol. 18, pp. 147-166.

[6] F. Chemat, N. Rombaut, A. Meullemiestre, M. Turk, S. Perino, A.-S. Fabiano-Tixier, and M. Abert-Vian, "Review of Green Food Processing techniques. Preservation, transformation, and extraction", Innovative Food Science and Emerging Technologies, June, 2017, vol. 41, pp. 357377.

[7] B. Golembiewski, N. Sick, and S. Bröring, "The emerging research landscape on bioeconomy: What has been done so far and what is essential from a technology and innovation management perspective?", Innovative Food Science and Emerging Technologies, May, 2015, vol. 29, pp. 308-317.

[8] F. Gaitis and G. Ouzounidou, "Food Safety: Strengthening the Present with an Eye to the Future", Journal of Innovation Economics and Management, 2017, vol. 3, issue 24, pp. 177-189.

[9] M. D. Robards, H. P. Huntington, M. Druckenmiller, J. Lefevre, S. K. Moses, Z. Stevenson, A. Watson, and M. Williams, "Understanding and adapting to observed changes in the Alaskan Arctic: Actionable knowledge co-production with Alaska Native communities", Deep Sea Research Part II: Topical Studies in Oceanography, June, 2018, vol. 152, pp. 203-213.

[10] A. Y. Prosekov and S. A. Ivanova, "Nutritional features of indigenous people of Siberia and North, America: Are we relatives?", Journal of Ethnic Foods, September, 2018, vol. 5, issue 3, pp. 155-160.

[11] T.-A. Kenny, "Chapter 24. Climate change, contaminants, and country food: collaborating with communities to promote food security in the Arctic", In: Predicting Future Oceans. Sustainability of Ocean and Human Systems Amidst Global Environmental Change, 2019, pp. 249263. 
2690451 S1 Russian Federation, IPC A21D 13/00 A23L 33/10 A21D 2/36, YNAO Arctic Scientific Research Centre, no. 2018122584/18, 06.03.2019, Bull. no. 16, 6 p.

[12] T.-A. Kenny, M. Fillion, and et al., "Calories are cheap, nutrients are expensive - The challenge of healthy living in Arctic communities", Food Policy, October, 2018, vol. 80, pp. 39-54.

[13] V. Amilien and H. Notaker, "Chapter 1. Health and Nutritional Perspectives on Nordic Food Traditions - An Approach Through Food Culture and History", In: Nutritional and Health Aspects of Food in Nordic Countries, 2018, pp. 1-31.

[14] L. P. Lobanova, A. A. Lobanov, and A. I. Popov, "Transformation of nutrition of the indigenous Nenets population", Sc. Bul. of YNAO, Salekhard, 2013, no. 4 (81), pp. 24-25.

[15] A. A. Lobanov and et al., "The composition for the preparation of crackers, food additive for it and the method of its preparation", Patent
[16] M. Wang and X. M. Yu, "Will China's population aging be a threat to its future consumption?", China Econ. J., October, 2019. Doi: 10.1080/17538963.2019.1681198.

[17] S. S. Ningthoujama, A. D. Talukdar, K. S. Potsangbam, and M. D. Choudhury, "Challenges in developing medicinal plant databases for sharing ethnopharmacological knowledge", Journal of Ethnopharmacology, 7 May, 2012, vol. 141, issue 1, pp. 9-32. 